\title{
PENINDASAN BURUH DALAM KUMPULAN PUISI NYANYIAN AKAR RUMPUT KARYA WIJI THUKUL SEBUAH TINJAUAN SOSIOLOGI SASTRA
}

\author{
Debora Martini Wulu dan Ali Nuke Affandy \\ SMA Kristen Gloria 2 Surabaya, Universitas Muhammadiyah Surabaya \\ Deborawulu123@gmail.com
}

\section{ABSTRAK}

ABSTRACT

PENDAHULUAN
Penelitian ini menggunakan teori sosiologi khususnya pada Sosiologi Sastra. Jenis penelitian ini penelitian kualitatif dengan pendekatan pragmatik. Sumber data penelitian ini yaitu Puisi Nyanyian Akar Rumput. Data penelitiannya berupa kalimat dan penggalan alinea. Teknik pengumpulan data dalam penelitian ini adalah teknik dokumentasi. Teknik analisis datanya menggunakan metode interaktif Miles Huberman yang berupa tiga tahap, yakni tahap reduksi data, penyajian data, dan penarikan kesimpulan serta verifikasi.

Kata Kunci: bentuk penindasan, jenis penindasan dan cara mengatasinya

This study uses sociological theory specifically in Sociology of Literature. This type of research is qualitative research with a pragmatic approach. The source of this research data is Poetry of Nyanyian Akar Rumput. The research data is in the form of sentences and paragraph fragments. Data collection techniques in this study are documentation techniques. The data analysis technique uses the Miles Huber-man interactive method in the form of three stages, namely the stage of data reduction, data presentation, and drawing conclusions and verification.

Keywords: The form of oppression, types of oppression, and how to overcome

Kita sering melihat fenomena dalam masyarakat di mana kita tinggal, kita dapat menjumpai orang-orang yang termasuk golongan kaya, sedang, dan miskin. Penggolongan tersebut menunjukkan bahwa di dalam masyarakat terdapat tingkatan-tingkatan yang membedakan antara manusia yang satu dengan manusia yang lain. Setiap masyarakat senantiasa mempunyai penghargaan tertentu dalam masyarakat yang bersangkutan dan setiap masyarakat pasti mempunyai atau memiliki sesuatu yang dihargainya. Sesuatu yang dihargai inilah sesungguhnya merupakan embrio atau bibit yang menumbuhkan adanya sistem berlapis-lapis, didalam masyarakat itu. Penghargaan yang lebih tinggi terhadap hal-hal tertentu, akan menempatkan hal tersebut pada kedudukan yang lebih tinggi.

Hal ini yang menyebabkan terjadinya pembedaan kelas sosial dalam masyarakat. Seperti kita dapat melihat dalam Kasus Marsinah adalah kasus yang melukis sejarah konflik secara vertikal 
di Indonesia. Konflik ini menjadi buah bibir di dalam masyarakat indonesai khususnya di Surabaya dan Sidoarjo. Kasus Marsinah adalah kasus antar kelas sosial yang ada dalam masyarakat Indonesia yaitu antara Kelas pengusaha atau orang yang mengusai alat produksi dan kelas buruh. Marsinah adalah sosok wanita pemberani dan setia kawan dengan menentang ketidak adilan dalam relasi pertukaran sosial yaitu kelas buruh memberikan jasanya untuk menghasilkan barang dan para pengusahan ingin mendapatkan barang yang akan dijual dan ditukar dengan uang, uang hasil penjualan tersebut sebagian untuk menggaji buruh tersebut. Kasus tersebut bermula Pada pertengahan April 1993, para buruh PT. CPS (Catur Putra Surya)-pabrik tempat kerja Marsinah-resah karena ada kabar kenaikan upah menurut Sudar Edaran Gubernur Jawa Timur. Dalam surat itu termuat himbauan pada para pengusaha untuk menaikkan upah buruh sebesar $20 \%$ dari upah pokok. http://www.kompasiana.com/asrinayuni/kasus$\underline{\text { marsinah }}$

Pada minggu-minggu tersebut, Pengurus PUK-SPSI PT. CPS mengadakan pertemuan di setiap bagian untuk membicarakan kenaikan upah sesuai dengan himbauan dalam Surat Edaran Gubernur. Keresahan tersebut akhirnya berbuah perjuangan. Pada tanggal 3 Mei 1993 seluruh buruh PT. CPS tidak masuk kerja, kecuali staf dan para Kepala Bagian. Sebagian buruh bergerombol dan mengajak teman-teman mereka untuk tidak masuk kerja. Hari itu juga, Marsinah pergi ke kantor Depnaker Surabaya untukmencari data tentang daftar upah pokok minimum regional. Data inilah yang ingin Marsinah perlihatkan kepada pihak pengusaha sebagai penguat tuntutan pekerja yang hendak mogok. Tanggal 4 Mei 1993 pukul 07.00 para buruh PT. CPS melakukan unjuk rasa dengan mengajukan 12 tuntutan. Seluruh buruh dari ketiga shift serentak masuk pagi dan mereka bersama-sama memaksa untuk diperbolehkan masuk ke dalam pabrik. Satpam yang menjaga pabrik menghalang-halangi para buruh shift II dan shift III. Tidak ketinggalan, para satpam juga mengibas-ibaskan tongkat pemukul serta merobek poster dan spanduk para pengunjuk rasa sambil meneriakan tuduhan PKI kepada para pengunjuk rasa. Ketika itu ada beberapa buruh yang di PHK tanpa di beri pesangon, ketidak adilan ini yang membuat marsianah menjadi geram dan melaporkan ketidak adilan para pengusa dalam negri ini. Akhirnya Marsinah pun diculik dan dibunuh serta di lecehkan yang terjadi pada tanggal 8 Mei 1993. Konflik itu pun merebak menjadi berita masal yang mengajak para kaum buruh terus protes. http://www.kompasiana.com/asrinayuni/kasus-marsinah

Negara Indonesia sekarang ini sedang menghadapi taraf tinggal landas. Akhir- akhir ini Indonesia disibukkan dengan salah satu masalah tentang kesejahteraan masyarakat di kalangan buruh. Buruh memerlukan perhatian pemerintah yang serius. Dikalangan buruh terdapatnya kesenjangan antara majikan dengan buruh, sehingga tidak terwujudnya masyarakat yang sejahtera dalam masyarakat Indonesia. 
Penggunaan kata buruh akan menggambarkan pertentangan antara kelas yang satu dengan kelas yang lain atau dalam bahasa sosiologinya terjadi pertentangan anatara kaum borguis dengan kaum proletar. Hubungan dari kedua kelas tersebut tidak sebanding atau memiliki perbedaan kepentingan. Buruh dianggap suatu kelas yang selalu dieksploitasi oleh kaum borguis, sehingga akan selalu berusaha menghancurkan borguis dalam perjuangannya. Buruh dipersepsikan sama dengan kelompok tenaga kerja dari golongan bawah yang bekerja hanya mengandalkan otot, sehingga orang orang yang bekerja tidak hanya menggunakan otot.

Setiap individu dalam masyarakat memiliki status sosialnya masing-masing. Status merupakan perwujudan atau pencerminan dari hak dan kewajiban individu dalam tingkah lakunya. Status sosial sering pula disebut sebagai kedudukan atau posisi, peringkat seseorang dalam kelompok masyarakatnya.

Pada semua sistem sosial, tentu terdapat berbagai macam kedudukan atau status, seperti anak, isteri, suami, ketua RW, ketua RT, camat, lurah, kepala sekolah, guru dan sebagainya.

Dalam teori sosiologi, unsur-unsur dalam sistem pelapisan masyarakat adalah kedudukan (status) dan peranan (role). Kedua unsur ini merupakan unsur baku dalam pelapisan masyarakat. Kedudukan dan peranan seseorang atau kelompok memiliki arti penting dalam suatu sistem sosial.

Kita tahu bahwa kelas sosial dapat sekali mempengaruhi status dan kedudukan seseorang. Dihargai dan tidak dihargai tergantung kedudukan atau posisinya dalam masyarakat.Seperti kita tahu bahwa Negara kita kaya akan SDM , tetapi kita tetap tidak memiliki kekayaan.

Seperti halnya kita dapat melihat keadaan kelas sosial di Indonesia seperti para pejabat, artis , dan orang pemilik modal mereka dapat melakukan apapun dengan modal yang mereka miliki. Seperti halnya kita melihat dari status pendidikan, kekayaan, kepintaran dan lain sebagainya, Indonesia juga merupakan Negara korupsi terbesar di dunia itu dapat terlihat dari para koruptor yang dapat membeli segala sesuatu dengan uang yang dikorupsi.

Kejadian-kejadian yang ada di tengah masyarakat itu merupakan realita yang dapat dijadikan bahan tulisan oleh berbagai pihak. Media massa, peneliti, pengamat, kriminolog bahkan pengarang karya sastra juga turut memanfaatkan realita tersebut. Pengarang mampu meramu realita di atas menjadi karya sastra, seperti puisi, cerpen atau novel.

Karya sastra adalah sebuah karya imajinasi yang bemedium bahasa. Bukti dari karya imajinasi tersebut dapat berupa novel, puisi, cerpen, dan lain sebagainya. karya sastra merupakan ungkapan pribadi manusia berupa pengalaman, ide, semangat, keyakinan dalam bentuk gambaran kehidupan. Dengan demikian, sebuah karya sastra tidak terlepas dari pengarang.

Karya sastra juga merupakan cerminan, gambaran, atau refleksi kehidupan masyarakat. Melalui karya sastra, pengarang berusaha mengungkapkan suka duka kehidupan masyarakat yang 
mereka rasakan atau mereka alami. Karya sastra menyuguhkan potret kehidupan menyangkut persoalan sosial dalam masyarakat, Setelah mengalami pengendapan secara intensif dalam imajinasi pengarang, maka lahirlah pengalaman kehidupan sosial tersebut dalam bentuk karya sastra.

Menurut Aritoteles, (dalam Sariban 2009:20) meskipun karya sastra meniru realitas, peniruan yang dilakukan pengarang bukan sekadar meniru apa adanya. Pengarang membentuk realitas baru berdasarkan realitas yang telah ada. Pengarang melakukan kreativitas untuk menciptakan kemungkinan-kemungkinan baru. Dengan demikian, karya sastra merupakan hasil kreatif pikiran perasaan dan perasaan manusia. Pengarang menyusun gambaran yang dapat dimengerti yang menampilkan kodrat manusia yang langgeng sehingga kebenaran dalam sastra bersifat universal. Karya sastra juga merupakan khayalan.

Karya sastra sebagai dunia fiksi atau khayalan berdiri di samping dunia kenyataan,yang beberapa aspek menunjukan persamaaan juga dengan kenyataan. Pemahaman dunia fiksi berangkat dari dunia kenyataan. Karya sastra juga merupakan tiruan atau jiplakan kenyataan kelahiran karya sastra disebabkan usaha "mencontoh" realitas. Kerja pengarang tidak lain adalah meniru objek-objek yang dilihatnya. Kerja pengarang tidak dari kerja tukang yang meniru objek-objek yang sudah ada. Karena karya sastra merupakan peniruan semata, mutu sebuah karya sastra lebih rendah dari mutu realitas itu sendiri (Palto dalam Sariban 2009:19).

Dengan hadirnya karya sastra yang membicarakan persoalan manusia, antara karya sastra dengan manusia memiliki hubungan yang tidak terpisahkan. Sastra dengan segala ekspresinya merupakan pencerminan dari kehidupan manusia. Adapun permasalahan manusia merupakan ilham bagi pengarang untuk mengungkapkan dirinya dengan media karya sastra. Hal ini dapat dikatakan bahwa tanpa kehadiran manusia, baik manusia sebagai sastrawan maupun sebagai penikmat sastra karya sastra tidak berfungsi dengan baik. Mencermati hal tersebut, jelaslah manusia berperan sebagai pendukung yang sangat menentukan dalam kehidupan sastra. Salah satu jenis karya sastra puisi bisa kita lihat dimana membahasa mengenai beberapa masalah salah satu masalah yang penulis kaji adalah masalah buruh indonesia terhadap kekuasaan dimana membahas mengenai buruh indonesia. Kekuasaan adalah kesempatan seseorang atau sekelompok orang untuk menyadarkan masyarakat akan kemauan-kemauannya sendiri dengan sekaligus menerapkannya terhadap tindakan-tindakan perlawanan dari orang-orang atau golongan-golongan tertentu.

Menurut Marx, hubungan antara kelas atas dan kelas bawah merupakan hubungan kekuasaan: yang satu berkuasa atas yang lain. Kekuasaan itu yang pada hakikatnya berdasarkan kemampuan majikan untuk meniadakan kesempatan buruh untuk bekerja dan memperoleh nafkah dipakai untuk menindas keinginan kaum buruh untuk menguasai pekerjaan mereka sendiri, untuk dihisap, agar 
kaum buruh bekerja seluruhnya demi mereka. Karena itu, kelas atas secara hakiki merupakan kelas penindas. Pekerjaan upahan, jadi pekerjaan di mana seseorang menjual tenaga kerjanya demi memperoleh upah, merupakan pekerjaan kaum tertindas: harapan dan hak mereka dirampas. Jadi, dalam hubungan produksi, yang berkuasa adalah para pemilik, sedangkan yang dikuasai adalah para pekerja. Dengan demikian, jika dikaitkan dengan puisi Wiji Thukul, dapat disaksikan kondisi perburuhan di Indonesia, maka kita akan dapat menyadari betapa kompleks dan rumitnya persoalan yang ada di dalamnya, dan hal itu tak kunjung ada penyelesaiannya.

Buruh pun berada dalam sebuah dilema, di satu sisi, mereka membutuhkan pihak perusahaan untuk bekerja danmendapatkan upah, namun di sisi lain, dalam pekerjaannya para buruh kerap kali dieksploitasi demi kepentingan pihak perusahaan tempat mereka bekerja. Persoalan tentang buruh dapat dikatakan sebagai persoalan yang krusial. Persoalan ini bukan sekadar persoalan industrial, tetapi juga menyangkut persoalan lain seperti sosial, ekonomi, dan politik. Dengan kata lain, sistem ekonomi-politik suatu negara akan menentukan corak sistem perburuhan dapat kita lihat bagaimana kondisi yang dialami oleh para buruh pada masa itu.

Puisi Wiji Thukul yang menampilkan potret buruh adalah Suti. Melalui puisi tersebut, Thukul menampilkan potret seorang buruh bernama Suti yang sakit akibat "terisap" oleh beban pekerjaannya yang berat, namun ia tidak memiliki cukup uang untuk berobat karena upahnya sebagai buruh tidak mencukupi. Sementara itu, dalam puisi Leuwigajah, Wiji Thukul menampilkan potret buruh (tenaga muda) yang terus diperah, diisap darahnya, seperti buah disedot vitaminnya.

Dalam puisi lain yang berjudul Terus Terang Saja, bahkan Wiji Thukul dengan terang-terangan menyatakan kapitalis sebagai musuh bagi mereka: kaum buruh. Dengan keras Thukul mengkonotasikan kapitalis sebagai sesuatu yangterus-menerus memakan tetes-tetes keringat kaum buruh. Nasib buruh memang sangat memperihatinkan, jika tak ingin disebut mengenaskan. Kapitalisme yang terus tumbuh dengan subur menyebabkan terjadinya kesenjangan sosial. Para pemilik modal yang banyak diantaranya adalah orang asing berusaha mencari keuntungan yang sebesarbesarnya dengan cara mempekerjakan buruh dengan upah yang rendah.

Buruh saat itu dituntut untuk bekerja dengan sangat keras, tetapi tidak diimbangi dengan upah yang sepadan. Belum lagi tentang banyaknya kisah penganiayaan terhadap buruh yang dilakukan oleh pihak perusahaan tempat mereka bekerja (ambil contoh kasus Marsinah, buruh dan aktivis yang meninggal sebab dibunuh oleh pemilik perusahaan tempatnya bekerja). Hal inilah yang banyak menjadi bahan protes sosial Wiji Thukul melalui puisi-puisinya. Pada tahun 2014, terbit kumpulan lengkap puisi Nyanyian Akar Rumput. 
Jenis penelitian yang digunakan dalam penelitian ini adalah kualitatif deskriptif artinya data yang dianalisis dan hasil analisisnya berbentuk deskripsi fenomena, tidak berupa angkaangka koefisien tentang hubungan antar-variabel. Data yang terkumpul berbentuk kata-kata atau gambar, bukan angka-angka. Tulisan hasil penelitian berisi kutipan-kutipan dari kumpulan data untuk memberikan ilustrasi dan mejadi materi laporan (Aminnudin, $1990: 16)$.

Dalam hal ini, akan diungkapkan data-data berupa uraianuraian dan percakapan-percakapan yang ada dalam puisi nyanyian akar rumput. Selain itu juga permasalahan-permasalahannya dianalissis dengan teori analisis yang digunakan yaitu teori kekuasaan. Hal-hal yang perlu dipaparkan dalam penelitian ini meliputi objek penelitian, sumber data, teknik pengumpulan data, dan teknik analisis data

Pendekatan sosiologi sastra jelas merupakan hubungan antara sastra dan masyarakat, literature s an exspreesion of society, artinya sastra adalah ungkapan perasaan masyarakat. Maksudnya masyarakat mau tidak mau harus mencerminkan dan mengespresikan hidup (Wellek dan Werren 1990:110)

Teori sosial dapat membantu kita memahami proses hubungan masyarakat dalam level sosial, organisasi dan individu(Ihlen, Ayvind; Fredrikson, Magnus.; Ruler, Betteke van, 2009:1).

Pendekatan sosiologi sastra terhadap hubungan masyarakat juga dapat memberikan pemahaman praktis terhadap level makro (organisasi) dan level mikro (individu). (Ihlen; Fredrikson, Magnus; Bettekevan, 2009:3).

Menurut Creswell (2003:1) penelitian kualitatif adalah sebuah proses penyelidikan untuk memahami masalah sosial atau masalah manusia, berdasarkan pada penciptaan gambaran holistik lengkap yang dibentuk dengan kata-kata, melaporkan pandangan informan secara terperinci, dan disusun dalam sebuah latar alamiah

Sumber data terkait dengan Subjek penelitian darimana data diperoleh (sigwankuro, 2014:72) keseluruhan sumber data data penelitian ini adalah kumpulan puisi Nyanyian Akar Rumput karya Wiji Thukul. Banyakny halaman 248, tebal halaman $20 \mathrm{~cm}$, namun tidak semua isi puisi di teliti tetapi diambil 22 puisi dari peterbitan PT Gramedia Pustaka Utama Jakarta 2014 , cetakan ke1.

Metode pengumpulan data yang digunakan dalam penelitian ini adalah metode pustaka, dan dokumentasi. Metode pustaka adalah metode yang menggunakna sumber-sumber tertulis untuk memperoleh data (Subroto, 1992:42). Metode dokumentasi berarti peneliti sebagai instrumen kunci melakukan pencatatan secara cermat, terarah dan teliti terhadap sumber data primer, yakni teks puisi nyanyian akar rumput untuk memperoleh data yang diinginkan.

Dengan metode pustaka berarti peneliti lebih dulu membaca teori-teori yang berkaitan dengan kelas sosial dan diskriminasi kaum buruh oleh kekuasaan, untuk menentukan data yang sesuai 
dan nantinya juga dijadikan landasan dalam menganalisis data. Sedangkan dalam metode dokumentasi, terdapat penemuan data dan penyampaian data yang kemudian diolah.

Prosedur yang dilakukan dalam pengumpulan data penelitian ini ialah

(1) Pengkodean sumber data dilakukan dengan pemberian kode, meliputi kode; fokus penelitian, subfokus penelitian, judul puisi dan kode halaman. Contohnya, Fokus Penelitian tentang kelas sosial buruh diberi kode KB; Subfokus Penelitian tentang hubungan kelas sosial kaum buruh diberi kode HKS, Judul puisi nyanyian akar rumput karya Wiji Thukul diberi kode BO; Halaman "diberi kode angka 124 dan seterusnya". Misalnya data tentang kelas sosial buruh diambil pada halaman 124 maka diberi kode data KB/DB/BO/124. Secara ringkas, pengkodean di atas dapat dideskripsikan seperti tabel berikut ini.

Hubungan kelas sosial buruh

\begin{tabular}{|c|c|c|}
\hline No. & Data & Kode Data \\
\hline 1 & & $\mathrm{BO} / \mathrm{HKS} / \mathrm{Tukul} /$ akar rumput/124 \\
\hline
\end{tabular}

Keterangan:

BO : Kelas sosial

HKS : Hubungan kelas sosial buruh

TUKUL : Pengarang

124 : Nomor Halaman

(2) Seleksi data di dalamnya adalah proses pemilhan dan penyaringan data sesuai dengan fokus dan tujuan penelitian yang ditetapkan. Seleksi data tersebut disesuaikan dengan kriteria-kriteria berikut: (a) data tersebut mengandung jenis kelas sosial (b) data mengandung pernyataan tentang diskriminasi buruh terhadap kekuasaan

(3) Pencatatan data ialah mencatat data dalam kartu data. Pencatatan itu dilakukan dengan menuliskan data yang telah mengalami pengkodean.

(4) Pengumpulan dan pemungutan data ialah proses terakhir dari prosedur pengumpulan data. Data yang telah dikumpulkan diurutkan sesuai dengan analisis yang akan dilakukan terhadap kalimat-kalimat, kata, atau frase yang mengandung jenis kecemasan dan mekanisme pertahanan terhadap kecemasan. Khusus mekanisme pertahanan peneliti hanya mengambil sepuluh macam saja, yakni: (1) represi, (2) sublimasi, (3) proyeksi, (4) pemindahan, (5) rasionalisasi, (6) pembentukan reaksi atau reaksi formasi, (7) melakonkan, (8) Isolasi, dan (9) intelektualisasi, dan (10) undoing .

(5) Kalimat, kata, atau frase yang mengandung deskripsi jenis-jenis kecemasan dan mekanisme pertahanan terhadap kecemasan dimasukkan dalam hasil penelitian. Referensi acuannya sama, 
PEMBAHASAN tidak semua dimasukkan dalam hasil penelitian, tetapi diambil satu atau dua yang dianggap mewakili.

Kekuasaan adalah kewenangan yang didapatkan oleh seseorang atau kelompok guna menjalankan kewenangan tersebut sesuai dengan kewenangan yang diberikan, kewenangan tidak boleh dijalankan melebihi kewenangan yang diperoleh atau kemampuan seseorang atau kelompok untuk memengaruhi tingkah laku orang atau kelompok lain .Kekuasaan bisa ada dimana-mana, bisa tentang apa saja meski kekuasaan tidak dapat dengan mudahdiperoleh tetapi kekuasaan akan menjadi suatu hal yang bisa dimiliki oleh siapasaja atas orang lain demi kelangsungan hidupnya.kekuasaan terbagi menjadi (a) hubungan kelas sosial (b) Diskriminasi

\section{Teori kelas sosial}

Merupakan teori yang berdasarkan pemikiran bahwa:"sejarah dari segala bentuk masyarakat dari dahulu hingga sekarang adalasejarahpertikaian anatara golongan". Analisa Marx mengemukakan bagaiamanahubungan antar manusia terjadi dilihat dari hubungan antara posisi masing-masing terhadap sarana-sarana Produksi, yaitu dilihat dari usaha yang berbeda dalam memanfaatkan sumber-sumber daya yang langkah. Dalam sub bab ini, peneliti menganalisis bagaimana hubungan kelas sosial yang terdapat dalam kumpulan puisi Nyanyian Akar Rumput karya Wiji Thukul. Hal ini dibuktikan dengan beberapa masalah yang pertama, bagaimana hubungan antara kaum atas dan buruh.

Hubungan kelas sosial buruh

\begin{tabular}{|c|c|c|}
\hline No & Data & Kode Data \\
\hline 1 & $\begin{array}{l}\text {... } \\
\text { apakah aku ini si bagero yang sudah } \\
\text { merdeka } \\
\text { ataukah tetap jugun ianfu yang tak } \\
\text { henti-henti diperkosa perusahaan } \\
\text { multinasional } \\
\text { yang menuntut kenaikan upah } \\
\text { ditangkap dan dijebloskan } \\
\text { ke dalam penjara?" } \\
\text { ("Terus Terang Saja") }\end{array}$ & $\begin{array}{l}\text { Bo/Hks/Tukul/akar } \\
\text { rumput/174 }\end{array}$ \\
\hline 2 & $\begin{array}{l}\ldots \\
\text { sudah lama, sudah lama } \\
\text { sudah lama kita saksikan } \\
\text { buruh mogok dia telepon kodim, } \\
\text { pangdam } \\
\text { datang senjata sebatalion kita } \\
\text { dibungkam" } \\
\text { ("Bukan Kata Baru") }\end{array}$ & $\begin{array}{l}\text { Bo/Hks/Tukul/akar } \\
\text { rumput/206 }\end{array}$ \\
\hline 3 & $\begin{array}{l}\ldots \\
\text { di mana-mana ada eman }\end{array}$ & $\begin{array}{c}\text { Bo/Hks/Tukul/akar } \\
\text { rumput/99 }\end{array}$ \\
\hline
\end{tabular}




\begin{tabular}{|l|l|c|}
\hline No & \multicolumn{1}{|c|}{ Data } & \multicolumn{1}{|c|}{ Kode Data } \\
\hline & $\begin{array}{l}\text { di bandung, solo, jakarta, tangerang } \\
\text { tak bisa dibungkam kodim }\end{array}$ & \\
& $\begin{array}{l}\text { tak bisa dibungkam popor senapan } \\
\text { satu mimpi satu barisan" }\end{array}$ & \\
& ("Satu Mimpi Satu Barisan") & \\
\hline
\end{tabular}

apakah aku ini si bagero yang sudah merdeka

ataukah tetap jugun ianfu yang tak henti-henti diperkosa perusahaan multinasional

yang menuntut kenaikan upah

ditangkap dan dijebloskan

ke dalam penjara?"

(Bo/Hks/Tukul/akar rumput/174)

Teori kelas sosial merupakan teori yang berdasarkan pemikiran bahwa: "sejarah dari segala bentuk masyarakat dari dahulu hingga sekarang adalah sejarah pertikaian anatara golongan". Analisa Marx mengemukakan bagaiamana hubungan antar manusia terjadi dilihat dari hubungan antara posisi masingmasing terhadap sarana-sarana Produksi, yaitu dilihat dari usaha yang berbeda dalam memanfaatkan sumber-sumber daya yang langka. Dalam kutipan puisi tersebut, Wiji Thukul mengibaratkan buruh seperti Jugun Ianfu, perempuan-perempuan yang dipaksa untuk menjadi pemuas nafsu tentara Jepang ketika masa penjajahan Jepang di Indonesia. Buruh seperti Jugun Ianfuyang tak hentihentinya diperkosa, dieksploitasi oleh perusahaan multinasional, namun dibayar dengan gaji yang murah. Apabila para buruh menuntut kenaikan upah, maka mereka harus siap ditangkap dan dijebloskan ke dalam penjara. Hal ini dapat dilihat bahwa terjadinya perbedaan kelas yang akhirnya membuat buruh ditindas karena mereka dikuasai. Dapat dilihat juga bahwa adanya hubungan yang tentunya tidak dekat antara buruh dan penguasa, karena buruh merupakan golongan kelas bawah.

\section{...}

sudah lama, sudah lama

sudah lama kita saksikan

buruh mogok dia telepon kodim, pangdam

datang senjata sebatalion kita dibungkam"

(Bo/Hks/Tukul/akar rumput/206)

Teori kelas sosial merupakan teori yang berdasarkan pemikiran bahwa: "sejarah dari segala bentuk masyarakat dari dahulu hingga sekarang adalah sejarah pertikaian anatara golongan”. Analisa Marx mengemukakan bagaiamana hubungan antarmanusia terjadi dilihat dari hubungan antara posisi masingmasing terhadap sarana-sarana Produksi, yaitu dilihat dari usaha yang berbeda dalam memanfaatkan sumber-sumber daya yang langka. Dalam kutipan puisi tersebut, Thukul menampilkan potret 
buruh yang melakukan aksi mogok kerja menuntut perbaikan upah yang kemudian ditanggapi oleh pihak perusahaan dengan cara menelepon militer (Kodim, Pangdam) untuk meredam aksi buruhPotret yang ditampilkan Thukul dalam puisi Bukan Kata Baru tersebut rupanya benar-benar pernah dialami oleh Thukul. Pada Desember 1995, Thukul yang saat itu merupakan anggota Partai Rakyat Demokratik (PRD) menggalang aksi mogok buruh PT. Sri Rejeki Isman Textile (Sritex). Aksi mogok kerja yang diikuti oleh belasan ribu buruh ituberakhir ricuh setelah secara tiba-tiba, aparat yang bertugas untuk menjaga aksi itu secara membabi-buta menyerbu para buruh. Dalam peristiwa itu, Thukul berhasil ditangkap dan secara bertubi-tubi aparat memukulnya. Tindakan kekerasan yang dilakukan terhadap Thukul itu bahkan mengakibatkan Thukul mengalami cedera serius pada bagian mata kanannya dan harus dioperasi.

\section{Diskriminasi}

Pengertian diskriminasi mencakup perilaku apa saja, yang berdasarkan perbedaan yang dibuat berdasarkan alamiah atau pengkategorian masyarakat, yang tidak ada hubungannya dengan kemampuan individuatau jasanya".Sedangkan Theodorson \& Theodorson (1979:115-116) mengartikan diskriminasi sebagai “...adalah perlakuan yang tidak seimbang terhadap perorangan, atau kelompok, berdasarkan sesuatu, biasanya bersifat kategorikal, atau atribut-atribut khas, seperti berdasarkan ras, kesukubangsaan, agama, atau keanggotaan kelas-kelas sosial'.Pengertian kedua definisi tersebut tidak jauh berbeda. Bahwa di sana ada membedakan tindakan berdasarkan atribut-atribut tertentu.

Diskriminasi kaum buruh oleh kekuasaan

\begin{tabular}{|c|c|c|}
\hline No & Data & Kode Data \\
\hline 1 & $\begin{array}{l}\text { k. } \\
\text { kuli-kuli perkebunan } \\
\text { seharian memikul kerja } \\
\text { setiap hari makin bungkuk } \\
\text { dijaga mandor dan traktor } \\
\text { delapan ratus gaji sehari } \\
\text { di rumah ditunggu } \\
\text { mulut-perut anak- } \\
\text { istri" } \\
\text { ("Gunung Batu") }\end{array}$ & $\begin{array}{l}\mathrm{Bo} / \mathrm{Hks} / \text { Tukul/akar } \\
\text { rumput/59 }\end{array}$ \\
\hline 2 & $\begin{array}{l}\text {... } \\
\text { buruh-buruh berangkat pagi } \\
\text { pulang petang } \\
\text { hidup pas-pasan } \\
\text { gaji kurang } \\
\text { dicekik kebutuhan", } \\
\text { ("Suti") }\end{array}$ & $\begin{array}{l}\mathrm{Bo} / \mathrm{Hks} / \mathrm{Tukul} / \mathrm{akar} \\
\mathrm{rumput} / 61\end{array}$ \\
\hline 3 & $\begin{array}{l}\text { dan upah kami dalam waktu singkat } \\
\text { telah berubah menjadi odol-sampo- }\end{array}$ & \\
\hline
\end{tabular}




\begin{tabular}{|c|l|c|}
\hline No & \multicolumn{1}{|c|}{ Data } & Kode Data \\
\hline & $\begin{array}{l}\text { sewa rumah dan bon- } \\
\text { bon di warung yang harus kami } \\
\text { lunasi." } \\
\text { ("Teka-teki yang Ganjil") }\end{array}$ & $\begin{array}{c}\text { Bo/Hks/Tukul/akar } \\
\text { rumput/96 }\end{array}$ \\
\hline
\end{tabular}

\author{
kuli-kuli perkebunan \\ seharian memikul kerja \\ setiap hari makin bungkuk \\ dijaga mandor dan traktor \\ delapan ratus gaji sehari \\ di rumah ditunggu \\ mulut-perut anak-istri"
}

(Bo/Hks/Tukul/akar rumput/59)

Penindasan diakibatkan adanya kesenjangan sosial baik antara si kaya dan si miskin yang biasa disebut kesenjangan ekonomi relatif maupun antara pribumi dan nonpribumi (Suaedy 2000:3-9). Kesenjangan terjadi karena adanya jarak yang jauh dari akumulasi ekonomi yang dimiliki oleh satu kelompok masyarakat dengan kelompok masyarakat lain. Misalnya banyak konglomerat yang Indonesia yang dimodali oleh bank-bank negara, sedangkan banyak pengusaha kecil ke bawah yang bangkrut, sehingga penumpukan modalnya sangat lambat sekali dan para pengusaha menengah ke bawah tersebut tidak dapat bekerja kembali. Dalam puisi tersebut, Wiji Thukul menampilkan potret buruh perkebunan yang setiap harinya menanggung beban pekerjaan yang berat, namun hanya mendapatkan upah delapan ratus rupiah tiap hari. Jumlah upah tersebut selain tidak sepadan dengan beban pekerjaan buruh yang begitu berat juga tidak mencukupi kebutuhan hidup keluarga seharihari. Selain beban pekerjaan buruh yang berat, rupanya tenaga buruh juga terus diisap oleh pihak perusahaan melalui lembur paksa. Persoalan lembur paksa memang merupakan salah satu hal yang seringkali dikeluhkan oleh buruh. Pihak perusahaan seringkali memaksa buruh untuk lembur kerja dengan dalih mengejar target produksi perusahaan. Dalam kasus ini, buruh dijadikan oleh pihak perusahaan tidak ubahnya seperti budak yang bebas diperlakukan dan diperintah apa saja.

\title{
buruh-buruh berangkat pagi \\ pulang petang \\ hidup pas-pasan \\ gaji kurang \\ dicekik kebutuhan" \\ (Bo/Hks/Tukul/akar rumput/61)
}

Penindasan diakibatkan adanya kesenjangan sosial baik antara si kaya dan si miskin yang biasa disebut kesenjangan ekonomi relatif maupun antara pribumi dan nonpribumi (Suaedy 2000:3-9). 
Kesenjangan terjadi karena adanya jarak yang jauh dari akumulasi ekonomi yang dimiliki oleh satu kelompok masyarakat dengan kelompok masyarakat lain. Misalnya banyak konglomerat yang Indonesia yang dimodali oleh bank-bank negara, sedangkan banyak pengusaha kecil ke bawah yang bangkrut, sehingga penumpukan modalnya sangat lambat sekali dan para pengusaha menengah ke bawah tersebut tidak dapat bekerja kembali. Kutipan puisi tersebut menggambarkan bagaimana upah yang rendah tidak cukup untuk memenuhi kehidupan sehari-hari buruh dan menyebabkan kehidupan mereka menjadi serba sulit. Lebih lanjut, Wiji Thukul menggambarkan potret kehidupan yang ditindas terus- menerus tanpa adanyaperhatian yang lebih dalam menjamin para pekerja atau buruh.

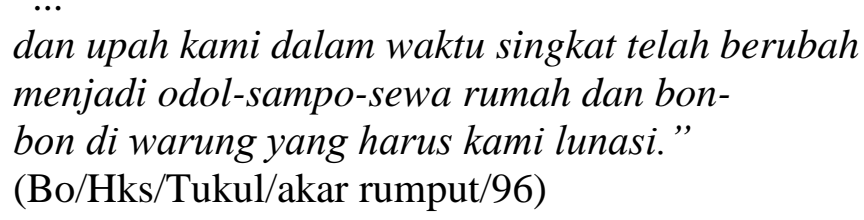

Penindasan diakibatkan adanya kesenjangan sosial baik antara si kaya dan si miskin yang biasa disebut kesenjangan ekonomi relatif maupun antara pribumi dan nonpribumi (Suaedy 2000:3-9). Kesenjangan terjadi karena adanya jarak yang jauh dari akumulasi ekonomi yang dimiliki oleh satu kelompok masyarakat dengan kelompok masyarakat lain. Misalnya banyak konglomerat yang Indonesia yang dimodali oleh bank-bank negara, sedangkan banyak pengusaha kecil ke bawah yang bangkrut, sehingga penumpukan modalnya sangat lambat sekali dan para pengusaha menengah ke bawah tersebut tidak dapat bekerja kembali. Untuk sekedar memenuhi kehidupan sehari-hari seperti "odol dan sampo" pun, para buruh masih merasa kesulitan, belum lagi ditambah hutanghutang mereka di warung dan uang biaya sewa rumah yang harus mereka lunasi. Bahkan, rendahnya upah yang diterima oleh para buruh ini juga berdampak pada ketidakmampuan mereka menyekolahkan anak mereka.

\section{SIMPULAN}

Berdasarkan analisis data yang telah dilakukan, dapat disimpulkan beberapa hal berikut.

1. Deskripsi Hubungan kelas sosial buruh Dapat disimpulkan bahwa dalam puisinya Wiji Thukul menampilkan berbagai potret keadaan buruh, hubungan dan status buruh yang sangat berbeda dengan penguasa atau kaum kapitalisme sepertipenindasan terhadap buruh seperti dieksploitasi oleh perusaha namun dibayar dengan gaji yang murah

2. Deskripsi Penindasan kaum buruh oleh kekuasaan dua puluh dua puisi Wiji Thukul tentang buruh yang terdapat dalam kumpulan puisi Nyanyian Akar Rumputmenampilkan berbagai potret buruh Indonesia, khususnya pada masa Orde Baru. Melalui 22 puisi tersebut, Wiji Thukul menampilkan berbagai 
potret keadaan buruh seperti potret kehidupan buruh yang sulit dengan upah yang tak sepadan dengam beratnya beban pekerjaan yang mereka tanggung.

\section{DAFTAR PUSTAKA}

Aminuddin. 1990. Pengembangan Penelitian Kualitatif dalam Bidang Bahasa dan Sastra. Malang: HISKI \&Yayasan Asah Asih Asuh.

Arifin Syarif, Panimbang Fahmi, Mufakhir Abu, Fauzan, Memetakan Gerakan Buruh. Jawa Barat: Kepik.

Depertemen Pendidikan Nasional. 2008. Kamus Besar Bahasa Indonesia. Jakarta: PT Gramedia Pustaka Utama.

Endraswara. Suwardi. 2003. Metodologi Penelitian Sastra. Yogyakarta: Pustaka Widyatama

Forse Bell Giddens. 2009. Sosiologi Sejarah dan Berbagai Pemikiranya. Bantul: Kreasi Wacana Offset.

Haryanto. 2012. Spektrum Teori Sosial, Yogyakarta: Ar-Ruzz Media

Mandel. 2006. Tesis-Tesis Marxisme. Yogyakarta: Resist Book

Nurgiyantoro, Burhan. 2002. Teori Pengkajian Fiksi. Yogyakarta: Gajahmada University Press.

Panibang, Arifin. 2012. Memetakan Gerakan Buruh. Jawa Barat: Penerbit Kepik.
Haryatmoko. 2014. Etika Politik dan Kekuasaan. Jakarta: PT Kompas Media Nusantara.

Muawijaya Andi. 2000. Peta pemikiran Karl Marx. Yogyakarta: LKIS

Rahman. Prabowo. 2013. Das Kapital. Yogyakarta: PT Buku Seru

Sariban. 2009. Teori dan Penerapan Penelitian Sastra. Surabaya: Lentera Cendikia.

Sugiyono, Metode Kuantitatif, Kualitatif dan $R \& D$. Bandung: Alfabet.

Thukul. 2014. Kumpulan puisi nyanyian akar rumput. Jakarta: PT Gramedia Pustaka Utama.

Weber.2009. Sosiologi. Yogyakarta: Pustaka Pelajar Offset.

Wellek, Rene dan Austin Warren. 2014. Teori Kesusasteraan. Terjemahan Melanie Budianta. Jakarta: PT Gramedia Pustaka Utama.

http://www.kompasiana.com/asrinayuni/ $\underline{\text { kasus-marsinah }}$

http://okayana.blogspot.co.id/2010/06/ke las-sosial-status-sosialperanan.html

http://ioapinino.blogspot.co.id/2011/10/k arl-marx-teori-kelas.html

http://any.web.id/arti-dan-macam$\underline{\text { macam-diskriminasi.info }}$ 